Whigham, S., Lopez-Gonzalez, H., \& Ramon, X. (2019). "Més Que Un Joc?”: Sport and Contemporary Political Nationalism in Scotland and Catalonia. Journal of Sport and Social Issues, 43(3), 219-244. http://doi.org/10.1177/0193723519836398

\title{
“Més Que Un Joc?”: Sport and Contemporary Political Nationalism in Scotland and
}

\section{Catalonia}

\begin{abstract}
This article focuses upon two contexts which have arguably received the most academic and media attention with regards to the interconnection between sport and secessionist nationalism, Scotland and Catalonia, given that both 'submerged nations' have held public referenda on the topic of independence / secession from the states of the United Kingdom and Spain, respectively. The analysis endeavours to draw parallels between the two contexts in order to critically examine the extent to which similarities and differences are evident in terms of the growth of political nationalism. Finally, the central discussion outlines the extent to which sport contributed to broader political developments in the recent campaigns for the establishment of independent Scottish and Catalan states, focusing upon the actions of prominent sporting personalities and organisations.
\end{abstract}

Keywords: sport, politics, nationalism, Scotland, Catalonia, independence, secessionism 


\section{“Més Que Un Joc?”: Sport and Contemporary Political Nationalism in Scotland and}

\section{Catalonia}

\section{Introduction}

Given the recent resurgence in support for supposed 'populist' political causes in a number of democratic states in Europe and North America, there has been a concomitant rise in academic and media analyses of the various factors which have contributed towards to the growing support for such causes (Judis, 2016; Moffitt \& Tormey, 2014; Mudde \& Kaltwasser, 2012). Recent political developments on a global, international, national and local level have therefore stimulated a lively debate about the nature of contemporary politics, with attention focused upon emergent issues such as: 1) the success of Donald Trump in the 2016 Presidential Election in the United States of America (Eiermann, 2016; Kazin, 2016; Kellner, 2016); 2) the victory of the 'Leave' campaign which led to the United Kingdom's withdrawal from the European Union (Clarke \& Newman, 2017; Freeden, 2017; Gusterson, 2017; Inglehart \& Norris, 2016); 3) the growth of populist parties on both the 'left' and 'right' of the political spectrum in countries such as Spain, Greece, Italy, Germany and the Netherlands (Mols \& Jetten, 2016; Wodak, 2015; Wodak, KhosraviNik, \& Mral, 2013; Yilmaz, 2012); and 4) the rising support for secessionist political nationalist movements which seek political independence for 'submerged nations' such as Scotland, Catalonia, the Basque Country, and Flanders, amongst others (Carbonell, 2018; Duerr, 2015; Guibernau, 2014; Keating, 1996).

Analyses of these developments have explored a myriad of contributory factors which can be argued to underpin these phenomena, with emphasis placed on: 1) the impact of the 2007-08 global economic and financial crisis (Inglehart \& Norris, 2016; Mols \& Jetten, 2016; Wodak, 2015); 2) a sense of public dissatisfaction with traditionally dominant political 
parties (Clarke \& Newman, 2017; Freeden, 2017; Mudde \& Kaltwasser, 2012); 3) the impact of changing global geopolitical relationships and economic production patterns on nations and their workforces in relation to immigration and outsourcing (Wodak, 2015; Yilmaz, 2012); and 4) the political, social and cultural practices of local populations in reaction to these global developments (Clarke \& Newman, 2017; Inglehart \& Norris, 2016).

In light of this broader global and political context, this article endeavours to contribute towards this ongoing debate by focusing its attention on one of the aforementioned developments: the rising support for secessionist political nationalist movements. In particular, this analysis will focus upon two contexts which have arguably received the most academic and media attention in this regard, namely Scotland and Catalonia, given that both 'submerged nations' have held public referenda on the topic of secession from the states of the United Kingdom and Spain, respectively. Although the nature of the political, economic, socio-cultural and legal contexts in which the 2014 Scottish and 2017 Catalan referenda were situated varied to a significant extent (Castello, Leon-Solis, \& O’Donnell, 2016; Duerr, 2015), this analysis will firstly endeavour to draw parallels between the two contexts in order to critically examine the extent to which similarities and differences are evident in terms of the growth of support for political nationalism in these contexts.

Having briefly outlined the broader political contexts, attention will then turn to the central foci of this article, namely, the relevance of sport to the development of secessionist political sentiment in Scotland and Catalonia. In terms of socio-cultural practices, sport has often been argued to possess a significant ability to either foster and/or negate political nationalism in various temporal and geographic contexts (Bairner, 2001; Cronin, 1999; Hargreaves, 2000; Maguire, 1999; Miller, Lawrence, McKay, \& Rowe, 2001; Silk, Andrews, $\&$ Cole, 2005). This analysis will therefore consider the extent to which sport contributed to broader political developments with regards to the recent campaigns for the establishment of 
independent Scottish and Catalan states, focusing upon the actions of prominent sporting personalities, organisations and clubs in relation to the current push for Catalan independence from the unitary Spanish state by Catalan political nationalists, as well as their corollaries in the Scottish context. This comparative analysis will therefore facilitate an appreciation of the nuanced relationship between sport and secessionist nationalism in contemporary Europe, allowing for critical reflection on the intricate and complex impact of contrasting sociocultural and socio-political factors which shape the role of sport within such political movements within these two different contexts.

\section{Sport and Political Nationalism in Scotland and Catalonia}

The cases of Scotland and Catalonia provide a complex analytical challenge in relation to the traditional theoretical conceptualisations of nationalism. Although the "nationstate' acts as the fundamental starting point for 'modernist' theoretical analyses, Scotland and Catalonia are prime examples of 'submerged nations' given their status within the wider state systems of the UK and Spain, respectively. Inhabitants of 'submerged nations', also known as 'stateless nations' (Guibernau, 2000; Schlesinger \& Benchimol, 2014), can possess a tangible awareness of their existence as a distinct 'nation' on a social, cultural and political level, despite their nation's lack of parallel representation in terms of sovereign statehood (Guibernau, 1995; Smith, 1999). To this end, numerous academics have considered the potential utility of sport for fostering nationalist sentiment in 'submerged nations' within existing state formations, such as the case of Scotland and Catalonia (Boyle, 2000; Boyle \& Haynes, 1996; Duke \& Crolley, 1996; Garcia, 2012; Iorweth, Hardman, \& Rhys Jones, 2014; McFarland, 2013; Nili, 2009; Vaczi, 2015). The following discussion therefore commences by providing a critical overview of previous academic writing on the relationship between sport, politics, and the cases of Scotland and Catalonia. 


\section{Political nationalism and sport in Scotland.}

In the Scottish context, despite the significant losses for the governance of Scottish society in the 1707 Act of Union, provisions were made to ensure that numerous elements of Scottish civil society were able to retain an element of autonomy and distinctiveness within the Union. The Act legislated for the maintenance of independent church, legal and educational systems following the Union, ensuring that the Presbyterian and Episcopalian systems of worship would remain as the 'established' churches of Scotland and England, respectively (Hearn, 2002; Larkin, 2011; Maclean, 2000; McCrone, 1992, 2005). McCrone (1992) and Pittock (2012) argue that these important concessions have had a significant long term impact in terms of maintaining the notion of Scotland as a distinct nation, due to the clear differences in relation to this 'holy trinity' of civil society which have existed between Scotland and England from 1707 to the present day. During this period, the constitution of the Union was rarely of political importance (Hanham, 1969; Harvie, 1998). For Harvie, this was due to the continued existence of 'semi-independence' for Scotland within the Union, echoing the arguments of McCrone (1992) regarding the importance of the 'holy trinity' of independent Scottish civil society.

Devine (1999) argues that the stability of the Union was secured due to the economic benefits which Scotland exploited during the eighteenth century, ensuring that the Scottish elite maintained their support for Scotland's constitutional status. However, the 1880s saw the issue of home rule for Scotland gaining prominence in political discussions, followed by further home rule movements in the 1910s. Indeed, a Scottish Home Rule Bill had progressed to its second reading by the outbreak of the First World War in 1914; however the advent of war meant that this Bill failed to progress into law (Devine, 1999; Hanham, 1969; Harvie, 1998). The inter-war period saw the establishment of other nationalist movements to replace the floundering home rule movement, with the establishment of the National Party of 
Scotland (NPS) in 1928 and the Scottish Self-Government Party (SSGP) in 1932 (Harvie, 1998; Lynch, 2009). In 1934, the NPS and the SSGP merged to form the Scottish National Party (SNP).

Whilst the post-war period marked the gradual consolidation of Labour as the dominant force in Scottish politics (Devine, 1999; Leith and Soule, 2011), the SNP failed to establish themselves as a significant force on the Scottish political scene until the 1970s (Leith and Soule, 2011; Lynch, 2009). Nonetheless, the success of the SNP in the February 1974 and October 1974 elections (with 7 and 11 MPs elected, respectively) saw the issue of home rule regaining traction (Harvie, 1998; Leith and Soule, 2011), framed within discussions of the 'democratic deficit' for the Scottish electorate with the 1979, 1983, 1987 and 1992 general elections all returning Conservative governments to Westminster in the era of 'Thatcherism' under Prime Minister Margaret Thatcher despite a growing majority of Labour MPs in Scotland (Hearn, 2002; Leith and Soule, 2011; Newby, 2009; Pittock, 2012; Sharp et al., 2014).

The election of the 'New Labour' government in 1997 was also significant for Scottish politics as it had committed to another referendum on Scottish devolution following the unsuccessful 1979 referendum (Devine, 1999; Leith and Soule, 2011; Maclean, 2000). The 1997 Scotland Bill which legislated for the devolution referendum led to reestablishment of the Scottish Parliament in 1999 with legislative powers over all areas except for 'reserved powers' which would remain under the Westminster Parliament. At the 2011 Scottish Parliament elections, the SNP was able to exploit dissatisfaction with the Labour government following the global financial crisis of 2007-2008, and the return of the Scottish 'democratic deficit' at Westminster with the establishment of the coalition between the Conservatives and the Liberal Democrats following the 2010 general election (Mycock, 2012). The result of the 2011 Scottish Parliament elections placed the SNP in a position to 
hold an independence referendum, with its 69 MSPs providing the party with an overall majority. The SNP-led Scottish government entered into negotiations with the coalition Westminster government, resulting in the signing of the 'Edinburgh Agreement' in October 2012 which legislated for a single-question referendum before the end of 2014, in line with the SNP's preference for a referendum date in autumn 2014.

With specific regard to sport and its symbolic resonance for Scottish nationalism, it has been argued that Scotland's possession of independent representative teams in international sport acts an additional element of civil society over and above the aforementioned 'holy trinity', thus facilitating an opportunity to maintain a distinctive notion of a Scottish 'nation' (Bairner, 1994, 1996, 2000; Blain, Boyle, \& O’Donnell, 1993; Boyle, 2000; Duke \& Crolley, 1996; Jarvie \& Walker, 1994). Given this anomaly in the international sporting system regarding the existence of separate Scottish representative teams in team sports, Bairner (2001) argues that the notion of Scottish nationhood and national identity are reinforced by the symbolism of sport, despite the lack of political independence for Scotland as a sovereign state. Furthermore, despite the fact that individual athletes from Scotland are often official representatives of the British sporting system, the Scottish media and general public tend to frame their achievements as Scottish rather than British sporting achievements (Blain et al., 1993; Boyle \& Haynes, 1996; Whigham, 2014).

However, despite the widespread academic agreement that sport acts as an important form of Scottish cultural nationalism and a medium for the expression of distinctive Scottish nationhood, the vast majority of analyses have also stressed that any attempts to conflate these expressions with support for Scottish political nationalism and/or the cause of Scottish independence are highly flawed (Bairner, 1994, 1996, 2001, 2015; Jarvie, 1993, 2017; Jarvie \& Walker, 1994, Kowalski, 2004). Nonetheless, the lack of synergy between sporting and political nationalism in the Scottish context does not mean that sport has remained free of the 
influence of political debates and causes. For example, during the 2014 Scottish independence referendum, sporting issues were frequently harnessed by both sides of the political debate, with the pro-independence and pro-union campaigns both citing support from sporting personalities for their respective political goals (Harris \& Skillen 2016; Jarvie 2017; Ochman 2013; Whigham \& May, 2017). Furthermore, the Scottish Government's White Paper on Scottish independence and their establishment of the 'Working Group on Scottish Sport' and the 'Sport for Yes' campaign groups illustrated that sport remained a consideration within the ongoing debates regarding the potential impact of Scottish independence for sport as an area of government policy (Lafferty, 2014; Scottish Government, 2013a, 2013b, 2014; Whigham \& May, 2017).

\section{Political nationalism and sport in Catalonia.}

It has been argued that Catalonia shares a number of similarities with Scotland in terms of its status as a 'submerged nation', with advocates of Catalan independence arguing that the nation has lost its historical sovereignty within the unitary state of Spain (Cuadras-Morato, 2014; Duerr, 2015; Guibernau, 2014; Ordeix \& Ginesta, 2014). Despite the fact that in the recent centuries it "has not existed as a political entity differentiated within the State" (Micó \& Carbonell, 2017, p. 430), Catalonia is considered to be one of the most "culturally distinct historical nationalities" (Olivieri, 2015, p. 1613) in Spain along with other two "Autonomous Communities': the Basque Country and Galicia, which comprise three of the six regions within Spain with co-official languages other than Spanish. However, the prominent signs of the Catalan identity go far beyond language (Prado, 2015; Schlesinger \& Benchimol, 2014). Indeed, Cuadras-Morato (2014, p.9) highlights that Catalonia possesses a number of independent civil institutions, thus resonating with McCrone's arguments regarding Scotland's 'holy trinity': 
Catalonia has many elements which form the foundations of its own national and/or cultural identity. Among others, there is Catalan, its own language, but also the multilingual character of the Catalan society, as the outcome of the diverse origin of a large part of its population. There are also its literature and other artistic manifestations, a rich set of traditions and folklore, its own civil law institutions and a long history as a largely self-governed entity until the end of the War of Succession in 1714.

Although Cuadras-Morato emphasises that the possession of such characteristics of a 'nation' does not necessarily result in broad acceptance of Catalonia's right to political self-determination. Other Spanish regions have been reluctant to acknowledge Catalonia's distinctiveness, especially considering that most of such autonomous regions (seventeen altogether) that comprise modern Spain have developed over time their own imagined community and sense of nationhood within the State. Nonetheless, the existence of signifiers of a distinctive Catalan identity within the Spanish state can be argued to play a part in the maintenance of Catalonia's sense of 'submerged' nationhood (Greer, 2007; Guibernau, 2014). Furthermore, the existence of pre-modern Catalonian principality prior to the 1714 War of Succession echoes the case of Scotland, allowing proponents of Catalan independence to claim a deep-rooted, ancient historical precedent for a Catalan nation, thus framing their political cause as an attempt to reclaim political sovereignty which has been 'lost' through past historical and constitutional developments (Duerr, 2015; Greer, 2007; Stout, 2016). For Guibernau (2014), such movements can be viewed as a form of 'emancipatory nationalism', with both the case of Catalonia and Scotland deemed to represent examples of emancipatory nationalism within the EU in the contemporary era. However, such contentions have proven contention for scholars of Spanish and Catalan 
history, given that the extent of Catalonia's historical independence is disputed (Chaytor, 1933; Greer, 2007; Guibernau, 2002, 2014).

A number of similarities and differences between Scotland and Catalonia emerge with regards to the maintenance of their status as a 'submerged nation' within a wider unitary state, and the later emergence of Catalan political nationalism. For example, similarities are apparent with regards to the initial consolidation of Catalonia within the newly-formed Spanish state in the 18th and 19th centuries, as the Catalan nation was integrated within the Spanish state through a process of political and cultural assimilation which replicated the Scottish case (Devine, 1999; Guibernau, 2014; Keating, 1996). Furthermore, in both contexts, this historical period saw little in the way of sustained political movements which successfully garnered support for political independence for Catalonia, which can at least be partially contributed to the growing industrialisation and economic development of the region within the Spanish state (Cuadras-Morato, 2014).

However, despite some temporal similarities in terms of the re-emergence of political nationalism in both nations in the late 19th and early 20th centuries (Devine, 1999; Harvie, 1998; Guibernau, 2014), the nature of the responses of the Spanish and British states to the rising tide of secessionist sentiment differed starkly. Whilst the British approach towards Scottish nationalism during the 19th and 20th century period tended to be more liberal and/or ambivalent in terms of its strategic position (Devine, 1999; Pittock, 2008), in contrast the Spanish state enacted a much more forceful and suppressive approach to Catalan cultural and political identity (Duerr, 2015; Guibernau, 2014) during this period. In particular, the period under the rule of General Franco's military-led regime in Spain after the Spanish Civil War saw the "suppression of Catalan political institutions, the banning of the Catalan language and the proscription of all the symbolic elements of Catalan identity, from the flag (the senyera) to the national anthem" (Guibernau, 2014, 
p.10). Whilst this violent suppression of Catalan identity in the era of Francoism differs starkly from the case of Scotland, the resultant effect of fostering a degree of grievance between Catalonia and Spain provided an alternative form of rationale for cleavage between the Catalan and Spanish nations. Therefore, if Scotland's political nemesis was deemed to be the Thatcher-led Conservative governments of the late 1970s and the 1980s (Hearn, 2014; Leith and Soule, 2011), then political nationalists in the Catalan context had a much greater foe in the form of Franco's regime (Duerr, 2015; Guibernau, 2014).

Furthermore, in contrast to the Scottish context, the continued existence of a widelyused Catalan language provides an additional cultural marker which distinguishes Catalonia from the Spanish state. Whilst the proportion of Scots who can understand Scottish Gaelic is very low (approximately $1 \%$ ), in Catalonia approximately $90 \%$ of the population can claim to understand the Catalan language in written or oral form (Duerr, 2015). Indeed, the promotion of the Catalan language has remained a key objective within the actions of the contemporary civil institutions within Catalonia, with all state education providers expected to teach students both the Catalan and Spanish languages (CuadrasMorato, 2014; Duerr, 2015; Guibernau, 2014; Ordeix and Ginesta, 2014). The maintenance and promotion of Catalan language has therefore acted as a central tenet of contemporary Catalan identity on both a practical and political level of operation, and has thus gained greater prominence within the Catalan nationalist cause in comparison to the case of Scottish nationalism, in which language has been a marginalised issue within the claims for Scottish independence (Leith and Soule, 2012; McCrone, 2017).

Analysis of the importance of sport in the context of the Catalan region has highlighted the pivotal role of FC Barcelona for the expression of regional and ethnic identities for the population of these regions (Duke \& Crolley, 1996; Vaczi, 2015). It has been argued that the club has become a "political institution" in Catalonia, "paralleling the 
development of the... Catalan national movement" (Nili, 2009, p. 246). Throughout the club's lifespan, it has actively acted as one of the "catalysers of the demands of nationalist groups" (Llopis-Goig, 2014, p. 825). Indeed, the Catalan region has witnessed the development of political nationalism which seeks to increase the democratic power of the regional parliament, either in the form of increased autonomy within a federalised Spanish state or as an independent and sovereign nation-state (Castello et al., 2016; Duke \& Crolley, 1996; Hargreaves, 2000; Vaczi, 2015). This echoes the earlier arguments of Blain, Boyle and O'Donnell (1993), whose analysis identified a 'unitary discourse' which emphasised the "unity of the Spanish nation" (p. 163), a 'disjunctive discourse' which emphasised the autonomy of Catalonia, and a middle-ground 'differential discourse' which possessed an ability to acknowledge the importance of peripheral regions such as Catalonia whilst still emphasising the role of central government.

Arguments of this ilk regarding the importance of sport for Catalan nationalism have also gained the attention of scholars from outside the domain of sport. For example, Duerr's (2015) thesis on secessionist nationalism in the context of Catalonia specifically identified the impact of sporting representation vis-à-vis the cause of Catalan political nationalism:

Another factor that has heightened the pro-independence movement in Catalonia might be linked to international sports. Although this connection is not overt, some of the interviewees noted the importance and power of sports in the national mobilization of Catalonia. Unlike Scotland, Catalonia does not have formal international sports teams. In essence, the Catalans do not have the same institutional advantages in FIFA, for example, as Scotland. However, Catalans do have the same advantages once a year when the Catalan "national" team is allowed to play against other national teams from across the world. (Duerr, 2015, p.106-107) 
The Catalan national team had already existed before Francisco Franco's regime but it was not until the late 1970s, with the recovery of democracy, when the tradition of friendly matches with other national teams was initiated (Nili, 2009). For Duerr, the creation and promotion of a representative Catalan football team offered an opportunity to bring the Catalan 'imagined community' to life, drawing upon the arguments of Anderson (1983) and Hobsbawm (1990) in this regard, as well as an ability to promote the symbols of 'banal nationalism' discussed in the work of Billig (1995), such as the Catalan flag and national anthem on an international stage. The popular demand for the rights of Catalan national teams to compete is by no means exclusive to football, since the campaign 'One nation, one team' (Xifra, 2009) has long advocated for the recognition of many sports including handball, basketball or roller hockey, to list a few. Nowadays, there are 21 minority sports in which Catalonia is officially recognised at the international level.

Nonetheless, most academic analyses have focused on the importance of football, and particularly the status of FC Barcelona and the Catalan 'national team', to the ongoing maintenance of a distinctive Catalan identity, both within Spain and on the global stage (Barcelo, Clinton, \& Samper Sero, 2015; Crameri, 2000; Garcia, 2012; Kassemeris, 2012; McFarland, 2013; O’Brien, 2013; Pujol \& Yuba, 2014; Shobe, 2006, 2008; Stout, 2016; Tunon \& Brey, 2012; Vaczi, 2014, 2017a, 2017b). However, many of these academics have also cautioned about the risks of over-simplifying the symbolism of FC Barcelona in relation to Catalan identity and political nationalism, arguing that the uncritical presentation of FCB and its mantra of 'Més que un club' ('More than a club') in this fashion runs the risk of ignoring the shifting positions of the club in relation to Catalanism, both historically and in the highly commercialised contemporary era where the financial implications of adopting a position other than relative neutrality within current political turmoil in Catalonia (Lopez- 
Gonzalez, Guerrero, \& Haynes, 2014; O’Brien, 2013; Vaczi, 2014, 2017a, 2017b). When Joan Laporta became FC Barcelona's president in 2003, the overt identification of the club with independence became remarkable (García, 2012). However, in the recent years, the club's decision-makers have played an ambivalent role when dealing with the referendum, emphasising its "historic commitment to the defence of the nation, to democracy, to freedom of speech, and to self-determination" (West, 2017) but avoiding comment on what they wanted the result to be. Despite retaining its symbolic power and influence over Catalan society, the club has neither embraced independents' or unionists' postulations in the referendum aftermath.

\section{Discussion}

Attention now turns to the central foci of this article, with the forthcoming discussion centring on a consideration of a number of comparative case studies which illustrate the relevance of sporting issues vis-à-vis contemporary secessionist political sentiment in Scotland and Catalonia. This analysis will therefore consider the extent to which sport contributed to broader political developments with regards to the recent campaigns for the establishment of independent Scottish and Catalan states, focusing upon the actions of prominent sporting personalities, organisations and clubs in relation to 1) the 2014 Scottish independence referendum campaign and 2) the October 2017 referendum on Catalan independence held by the Catalan government. In particular, the framing of sporting issues within media and political debates on the constitutional futures of Scotland and Catalonia will be scrutinised, thus facilitating a critical reflection on the pertinence of sport in relation to political nationalism in each context. 


\section{Sport and Contemporary Scottish Politics - A Precarious Position?}

Analysis of the inter-connection between sport and the political debate regarding the 2014 Scottish independence referendum identifies a number of interesting emergent patterns. The first of these emergent issues is the extent to which sporting personalities were embroiled within the referendum debate, with heightened interest paid to the political opinions of current and former sportspeople in relation to the Scottish constitutional question. In particular, the cases of tennis player Andy Murray, athlete Lynsey Sharp and cyclist Sir Chris Hoy received a notable attention in the media during the referendum debate, given the contrasting responses to questions on the topic of Scottish independence.

For example, Andy Murray’s global status as a world-leading tennis player, with three 'Grand Slam' titles and a period at the top of the ATP World Rankings, arguable rendered him the highest-profile Scottish sporting personality at the time of the 2014 referendum. Murray's past comments to the media regarding his lack of support for the English football team in the World Cup have seen Murray rendered as 'anti-English' by certain elements of the press (BBC, 2006; Harris \& Skillen, 2016; Haynes \& Boyle, 2008), leading to questions of Murray's identification as a Scottish rather than British representative. Murray's past exploits have also been embroiled with political debates prior to the 2014 independence referendum, with the contested framing of Murray's success at London 2012 Olympics, the 2012 US Open and the 2013 Wimbledon competitions by the British Prime Minister David Cameron and the Scottish First Minister Alex Salmond in relation to Britishness and Scottishness acting as a bone of contention in media and political circles (Harris \& Skillen, 2016; Sharp, Cumbers, Painter, \& Wood, 2014; Shipman, 2014; Weisbloom, 2012). However, Murray himself explicitly strayed into the public debate at the very final stages of the 2014 Scottish independence referendum debate, sending a tweet in the early hours on the day of the referendum on $18^{\text {th }}$ September 2014 stating: 
Huge day for Scotland today! no campaign negativity last few days totally swayed my view on it. excited to see the outcome. lets do this! (https://twitter.com/andy_murray; 18th September 2014)

Murray's comments were quickly seized upon political groups and media outlets, with the official pro-independence 'Yes Scotland' campaign group widely promoting the comments as an explicit endorsement of a 'Yes' vote, and thus capturing a significant amount of coverage in both the print and electronic media on the day of the referendum. However, given that the editorial positions of the vast majority of Scotland-based and London-based newspapers was either pro-union or neutral (Dekavalla, 2016; Mullen, 2014), the reaction of the media tended to frame Murray's comments using phrases from 'ill-advised' to 'irresponsible' and 'sickening' (Alexander, 2014; Blundy, 2014). One such piece argued:

This huge groundswell of goodwill for Our Andy may now have evaporated for many and will take an awful lot of recovering. Not just outside Scotland but also inside as well, where previously unconditional devotees supporting the No campaign will feel aggrieved. Retribution was swift in coming on social media and some of it sickening, although the backlash from the Cybernats [derogatory term to refer to the online supporters of the Scottish independence] would have been even more vicious if he had come out supporting the union. (Dickson, 2014)

Furthermore, as alluded to by Dickson's article in the Daily Mail, Murray's comments also resulted in an extreme reaction on social media platforms such as Twitter from both sides of the constitutional debate. Whilst pro-independence campaigners lauded Murray's intervention as a support for a 'Yes' vote, Murray was also barraged with a plethora of negative and abusive comments from social media users from the opposite side of the 
political debate. Given the vitriolic nature of the reaction to Murray's support for the 'Yes' campaign, including the references to Murray's presence at Dunblane Primary School during the mass shooting and murder of 17 5-year-old pupils by lone gunman Thomas Hamilton, it is unsurprising that Murray expressed regret about his comments during the referendum (McLeman, 2016; Prynne, 2014), and would thus be refraining from future political comments of this ilk. However, Murray was not alone in the sporting domain in terms of receiving opprobrium for straying in to the Scottish independence debate, as evidenced in the cases of Lynsey Sharp and Chris Hoy. Sharp's achievement of a silver medal in the $800 \mathrm{~m}$ event at the Glasgow 2014 Commonwealth Games had resulted in an increased level of media interest in her career, and in the final stages of the 2014 independence referendum campaign she became a vocal advocated of a 'No' vote by appearing on a BBC-hosted radio debate on 9th September 2014 to illustrate her concerns about the implications of a 'Yes' vote (BBC 2014; The Herald, 2014):

...my particular concerns are whether Scotland, as an independent country, would have the funds, time and the resources to achieve the same sporting success as we're able to do so at the moment through a British team. Secondly I think... it's unlikely that the Scottish athletes would be able to compete for Scotland at Rio. (The Herald, 2014)

Furthermore, Sharp also explicitly identified her support for a 'No' vote on the day of the Scottish independence referendum, releasing a tweet with the message "\#Scottish \#British \#bettertogether" in conjunction with two different images of her holding the Scottish flag and the British flag aloft after competition (https://twitter.com/LynseySharp; 18th September 2014). The symbolism of the Sharp's message thus illustrated the dualism of Scottish and British identity shared by a number of Scots in the sporting world and the general public, as 
has been commented upon elsewhere (Iorwerth et al., 2014; Jarvie \& Reid, 1999; McDowell \& Skillen, 2015). However, the reaction to Sharp's tweet was as equally vitriolic as the response to Murray's intervention.

Furthermore, despite attempting to maintain a degree of political neutrality on the constitutional question, Sir Chris Hoy also found himself to be embroiled within the political debate and the victim of a social media backlash. For example, Hoy's comments that Scottish athletes might face challenges in terms of competing at Olympic level were quickly framed as a tacit support for the pro-union campaign despite Hoy's objections (BBC, 2013; Howson, 2014; Roden, 2013), as were his comments regarding his pride at being able to represent both Scotland and Britain in various international competitions (BBC, 2013). Indeed, these comments from Hoy are arguably unsurprising given that his status as Scotland's most successful Olympian, with six gold and one silver medal, was secured whilst receiving support from the cross-UK British Cycling sporting infrastructure from his training base location in Manchester, England. Nonetheless, these comments led to polarised social media reaction, with lauding of the comments by pro-union campaigners and an abusive reaction from pro-independence activists. Hoy was branded a 'traitor' and 'bigoted anti-Scot' by 'Yes' campaigners, leading to sympathetic coverage of Hoy's predicament by pro-union media outlets, accompanied by negative framing of the abusive 'Cybernats' (Johnson, 2013; Roden, 2013; Swanson, 2013).

Despite these negative reactions to the comments of active sports personalities such as Murray, Sharp and Hoy, a final emergent pattern with regards to sport's links to the 2014 independence debate was the growing trend for endorsements from retired sportspeople. The pro-union 'Better Together' campaign was able to coordinate support from a range of personalities from the two most popular sports in Scotland, football and rugby, including high-profile celebrities such as Sir Alex Ferguson, Denis Law, David Beckham, Sir Ian 
McGeechan, Gavin Hastings and David Sole (Crichton, 2014; Whitaker, 2014), and was thus more successful in this regard. However, the establishment of the 'Sport for Yes' campaign group by pro-independence campaigners illustrated a degree of success in this regard (Lafferty, 2014; Whigham \& May, 2017). Therefore, despite the questionable impact of sports-related political interventions during the referendum campaign, the growing trend for endorsements for a 'Yes' or 'No' vote from sporting personalities became apparent during the closing weeks of the Scottish independence referendum campaign (Harris \& Skillen, 2016; Jarvie, 2017) and a growing trend for endorsements for a 'Yes' or 'No' vote from sporting personalities became apparent (Harris \& Skillen, 2016; Jarvie, 2017), suggesting that the potential risks of political interventions such as these were reduced for those who were no longer actively competing.

\section{Sport and Contemporary Catalan Politics - Més Que un Joc?}

As was the case during the 2014 Scottish independence referendum campaign, the ongoing political turmoil in Catalonia similarly led to growing interest in the political opinions of high-profile Catalan sporting personalities. This therefore led to a significant degree to media coverage and debate of any particular statements made by sportspeople on the topic, as well as frequent questioning of athletes during their media duties in press conferences. Unsurprisingly, any comments which could have possibly been construed as either an explicit or implicit endorsement of either a pro-independence or pro-union stance received a significant degree of interest. In a highly polarised landscape, Catalan and Spanish media capitalised on those comments and framed them according to their differentiated ideological position with regard to the referendum (for, against, or in favour of the 'right to decide') (Micó \& Carbonell, 2017). Furthermore, when compared to the period of the Scottish independence referendum, it appeared that the Catalan context witnessed a slightly 
higher degree of willingness from high-profile sportspeople to make political comments with regards to the topic of Catalan independence.

However, one of the central reasons for the prevalence of such comments from Catalan sporting personalities appears to be attributable to the disputed legitimacy of the various attempts by pro-independence Catalan political organisations to host public referenda on the constitutional question, given that Catalonia had failed to reach any such legally binding agreements with the central Spanish government (Cuadras-Morato, 2014; Duerr, 2015; Guibernau, 2014). Given this, and the resultant violent clashes between government forces and members of the public attempting to vote in the referendum on the $1^{\text {st }}$ October 2017 , a number of sporting personalities felt compelled to make comments which refuted the violent scenes in certain locations in Catalonia, even if they refused to state whether they personally supported independence or not. For example, Pau Gasol of the NBA's San Antonio Spurs commented on the violence on Twitter soon after the vote:

This is where we had to reach? Was violence necessary? [A esto hemos tenido que llegar? Era la violencia necesaria?] \#NoALaViolència \#SiAlDiàleg \#StopViolence \#Dialogue \#NoAlaViolencia \#SiAlDiálogo (https://twitter.com/paugasol; 1st October 2017)

Indeed, despite Gasol's express reservations in the past about making political statements, arguing that "my political views are private and that's the way they'll stay because I don't like my words being twisted in times of success" (Marca, 2015), the resultant violence led to Gasol's willingness to participate in the political debate regarding the right for Catalans to vote peacefully, even if such an intervention did not necessarily align with either side of the constitutional debate: 
"I am always in favour of voting" says Gasol when asked if he will participate in the consultation. "I do not know if I will do it, but I am always in favour of voting, of exercising your right and of having an opinion on a possible social situation that will affect you, your friends and your family." [translated from Spanish] (AS, 2017)

Gasol's arguments regarding the importance of maintaining peaceful democratic practices in relation to the Catalan political question were similarly expressed by a number of other highprofile Catalan sporting personalities, suggesting that making such comments was deemed to be relatively uncontroversial as they did not necessarily mean expressing either support or opposition to Catalan independence. FC Barcelona captain Gerard Piqué echoed the comments of Gasol with regards to the importance of a peaceful democratic process, again taking to Twitter to state:

From today and until Sunday, let us express ourselves peacefully. Let's not give them any excuse. It is what they want. And let's sing loud and clear. [Des d'avui i fins diumenge, expressem-nos pacíficament. No els hi donem cap excusa. És el que volen. I cantem ben alt i ben fort.] \#Votarem (https://twitter.com/3gerardpique; $28^{\text {th }}$ September 2017)

I have already voted. Together we are unstoppable defending democracy. [Ja he votat. Junts som imparables defensant la democràcia.] (https://twitter.com/3gerardpique; 1st October 2017)

"It has been the worst experience as a professional of my life. People have gone to vote peacefully and the treatment of the Civil Guard and the police speaks for itself. The acts of today have seen the whole world and there will be consequences" 
commented the Catalan central, who seized by emotion had to stop several times. (Ruiz, 2017)

Piqué was joined by a number of other sporting personalities making comments to this effect, including Barcelona team-mates Carles Puyol and Xavi Hernández (E1 Periódico, 2017), and other retired players from the club such as Pep Guardiola and Oleguer Presas (Sport, 2017a, 2017b; Telegraph, 2017). Comments to the contrary on the legitimacy of holding a referendum were comparatively rare, with the comments of Spanish tennis player Rafael Nadal at a press conference at the 2017 US Open the only high-profile intervention of this nature:

"I feel very close to the Catalans, I feel very Spanish too. I do not understand a Spain without Catalonia. I would not like to understand it or see it. I understand that together we should be able to understand, without any doubt, and I believe that an effort has to be made to reach an understanding because I believe that we are, without any doubt, stronger together than separated. Both Spain is better with Catalonia and Catalonia is better with Spain, from my point of view. I think that October 1 should not be produced because, from my point of view, everyone has to respect the laws and there are laws that are what they are and you cannot skip the laws because you want to skip them.” (Martinez, 2017)

These interventions, amongst others, illustrate the increased willingness of sportspeople intervening in the Catalan political debate in comparison to the Scottish context, as outlined above. Nonetheless, despite the prevalence of political comments supporting the right to hold a referendum on Catalan independence, it would be premature to contend that such statements were deemed to be simply a defence of democratic rights, with a emergent 
tendency for the media to portray such comments as an implicit endorsement of Catalan independence. This was particularly evident in the case of Piqué, given that he has often been portrayed as a Catalan nationalist in the past and his participation in the Spanish national team has drew media attention in this regard (Lowe, 2017; Torres, 2017a, 2017b; West, 2017). To this end, Piqué explicitly highlighted his preference to remain politically neutral: When Piqué was asked if he was in favour of independence, he said: "That's the million dollar question and I am not going to answer it. Football players are global figures and I can't come out for one side or the other. For example, in Catalonia or in Spain, I would lose half of my followers. And all because people put politics before everything else," he said. "My sons, for example, are Colombian, Lebanese, Catalan and Spanish. We are in a global world. I think that my answer is not the important issue. There's a serious political problem in Spain which is getting worse and the solution can be found through dialogue. (Sport, 2017c)

Piqué's attempts to explicitly highlight that his interventions did not act as an endorsement of Catalan independence thus illustrates that, similar to the Scottish context, any specific indication of support for a political constitutional outcome remained a risky endeavour for sporting personalities, whether for personal or commercial reasons. Indeed, Piqué's comments about losing "half of my followers" had he made any such political statements further illustrate the commercial implications of political statements by sportspeople, and thus mimic the arguments of past analyses of the shifting rhetoric of FC Barcelona as a club in relation to the Catalan political climate and the club's commercial considerations (Lopez-Gonzalez et al., 2014; O’Brien, 2013; Vaczi, 2014, 2017a, 2017b). Other high-profile sporting celebrities in the Catalan context, such as the motorcyclist and four-time MotoGP World Champion Marc Márquez, also deliberately endeavoured to 
emphasise their political neutrality as was the case for Piqué. In the case of Márquez, the political symbolism of his choice of a personal flag emblazoned with his preferred '93' logo over the Spanish or Catalan national flags has been specifically identified as a symbol of his political neutrality:

He was celebrating the championship title he had just won. As he headed back to the pit, where his team was waiting for him, they gave him the flag. It didn't have his number on it: the '93.' But instead an enormous '1,' the number of champions. It's been four years since Marc Márquez, the motorcycle racer from Cervera (Catalonia) has flown a Spanish flag at circuits. Neither has he ever been seen with a senyera, the official flag of the northeastern Spanish region. (Tronchoni, 2017)

Nobody should be surprised that, in the end, the rider of Cervera has chosen not to draw the constitutional flag. He has not done so since 2013. However that does not mean that on many occasions Márquez has not pronounced on the subject of Catalonia (in the same sense as Nadal, Mireia Belmonte and Saúl Craviott or among others). He, explain those who know him, does not want to offend anyone. (Landaluce, 2017)

In this regard, it should be reminded that regional flags have played "an important symbolic role in modern Spain" (Olivieri, 2015, p. 1615). The tensions between the Spanish and Catalan flags have long crystallised within and beyond the sporting arena (Crexell, 1994; Hargreaves, 2000).

Whilst active sportspeople such as Gasol, Piqué and Márquez tended to avoid explicitly endorsing the push for Catalan independence, other high-profile sportspeople were more willing to nail their colours to the mast, again replicating the Scottish context. For example, 
individuals such as Pep Guardiola and Oleguer Presas, both ex-Barcelona players, have been very active in terms of media comments on the topic of Catalan independence (Marca, 2012, 2017a, 2017b; Ruiz, 2017; Sport, 2016). In particular, the case of Guardiola has been of specific note in this regard, given his status as a global figure the current head coach of Manchester City FC, his past success as manager of FC Barcelona, and his exploits as a player for both FC Barcelona and the Spanish national team. Guardiola has been unequivocal in his support for both the hosting of a referendum on Catalan independence, as well as his personal support for the establishment of an independent Catalan republic state (Delaney, 2017; Marca, 2017a, 2017b). Furthermore, Guardiola's ongoing support for the 'yellow ribbon' protest against the imprisonment of Catalan politicians and activists by the Spanish courts following the 'illegal' hosting of the independence referendum on $1^{\text {st }}$ October 2017 (The Guardian, 2018; Whittell, 2018), thus indicating his political position explicitly: "I hope that the politicians in prison can leave as soon as possible for their families," he [Guardiola] said. "If it can happen to them then it can happen to us. For giving an opinion. People shouldn't be confused and think it couldn't happen to them, because it can. We cannot ignore that these eleven politicians or activists, who haven't hurt anyone, are in prison for asking to vote. Many things have happened but it's all because we wanted to vote, because we wanted a legal referendum. The solution is that the state and Catalonia should agree and we can have an agreed referendum. It's as simple as that." (de Grado, 2017)

However, despite Guardiola's relatively greater scope for intervening in the political debate in terms of the media coverage and reception of his comments in comparison to active sportspeople, his willingness to speak out on this issue did result in some personal ramifications. Firstly, his active participation in the 'yellow ribbon' campaign resulted in 
fines from the Football Association in England (The Guardian, 2018; Whittell, 2018). Secondly, and more significantly from a political perspective, Guardiola also found himself under investigation by the Spanish authorities who accused Guardiola of providing the fugitive Catalan nationalist political leader Carles Puidgemont with refuge on his private aeroplane (Llorens, 2018), as well as investigating Guardiola for 'rebellion' during the referendum campaign (Whaling, 2017). This illustrates that such political interventions remain a risky endeavour for all sporting personalities, whether active or retired.

\section{Conclusion}

Given the exhaustive list of issues which have become politicised by both sides of the debates with regard to the debate on Scottish and Catalan independence, it is unsurprising that central considerations relating to economics, currency, defence, social justice and membership of the EU have dominated over relatively marginal topics such as sport (Cuadras-Morato, 2016; Duerr, 2015; Harris \& Skillen, 2016; Jarvie, 2017). Furthermore, it can also be argued that the strength of the relationship between sporting nationalism and political nationalism remains questionable, with the attention of pro-independence and prosecession movements instead focused upon wider economic and societal campaign issues. Indeed, Jarvie (2017) concluded that:

...during the Scottish Referendum campaign sport was neither a driver of cultural or political nationalism nor a hotly contested political issue. This is in the sense that it had no real political power in helping either the Yes or No campaign to achieve their political goals or influence Yes or No voters which way to vote. (2017: 219)

Nonetheless, the analysis of media and political discourse provided above illustrates that sport remained a phenomena of interest with regards to the understanding of cultural and 
political nationalism in both the Scottish and Catalan contexts. Despite the potential implications for the public image and commercial considerations of high-profile, activelycompeting athletes (Brentin, 2016), the cases of Murray, Sharp, Hoy, Piqué, Gasol and Nadal demonstrate that the willingness of sporting personalities to stray in to the respective political debates render this an ongoing area of academic interest. Whilst the degree of political involvement of sporting personalities was relatively rare in comparison to other areas of civil society, such as the arts, culture and academia amongst others, the potentially greater symbolic influence of sporting personalities and institutions on their respective publics renders these rare interventions of significant interest.

Furthermore, this comparative analysis demonstrated the nuanced relationship between sport and secessionist nationalism in contemporary Europe through its comparative discussion of the Scottish and Catalan contexts. First and foremost, the major contextual difference between these two states lies in the contrasting legal status of the independence referenda in each context, with the Scottish referendum of 2014 having being offered an official legal status by the UK government, contrasting with the Spanish state's recalcitrant stance to the Catalan referendum in October 2017. Importantly, this difference resulted in a re-framing of the nature of the political interventions of the Catalan sporting personalities, which often struck the tone of a protest movement in support of democratic freedoms and thus did not necessarily require Catalan athletes to specifically declare their support for independence. In contrast, the legal footing and binary nature of the Scottish referendum meant that any political pronouncements in that context were viewed as an explicit or implicit support for a 'Yes' or 'No' vote. Given this, it is perhaps unsurprising that the frequency of endorsements from active sporting personalities in the Scottish context was comparatively lower than in the Catalan context, as outlined in the discussion above. 
In a similar vein, the comparative nature of the above discussion also highlighted the impact of Scotland's unique status in the international sporting context with its independent representative teams, an opportunity which Catalonia (and other 'submerged nations') have sought to emulate, whilst the existence of a widely-used distinct Catalan language provides a marker of national identity which is absent in the Scottish context. The comparative nature of the discussion has thus explicitly demonstrated that nuanced historical, socio-cultural and political differences between the two contexts have influenced the manner in which the relationship between sport and secessionist nationalism has manifest itself in each 'nation'.

Although sport will undoubtedly remain on the periphery of the ongoing constitutional debates in Scotland and Catalonia, the numerous examples outlined above serve to demonstrate that any attempts to dismiss the political import of sport as a cultural phenomenon would be hasty. Given that sporting personalities already possess a public platform which, rightly or wrongly, heightens the potential influence of any political statements on these contentious matters, the relatively rare interventions of sportspeople into the public and media debates on the topics of Scottish and Catalan independence will continue to garner significant attention. Whilst those who continue to perpetuate the "myth of autonomy' in relation to the apolitical nature of sport, including sporting organisations, commercial partners and certain media commentators, will certainly continue to admonish sportspeople who venture in to the political domain, there will be many others who will echo the arguments of Gerard Piqué in this regard: “we're footballers but we're people too. Why can a journalist or a mechanic express themselves but not a footballer?" (Lowe, 2017). For academics with an interest in the interconnections between sport, politics and nationalism, Piqué's arguments will continue to emphasise the importance of critical analysis of the significance of sport in such debates. 


\section{References}

Alexander, E. (2014, 18 September). Andy Murray branded 'irresponsible' for revealing 'extremely ill-advised' Scottish Independence view on Twitter. The Independent. Retrieved from http://www.independent.co.uk/news/people/andy-murray-brandedirresponsible-for-revealing-extremely-ill-advised-scottish-independence-view9740707.html

Allison, L. (2000). Sport and nationalism. In E. Dunning (Ed.), Handbook of sports studies (pp. 344-355). London: Sage.

Anderson, B. (1983). Imagined communities: reflections on the origins and spread of nationalism. London: Verso.

AS (2017, 10 July). Pau Gasol, on the referendum in Catalonia: "I am always in favour of voting" [Pau Gasol, sobre el referéndum en Cataluña: "Siempre soy partidario de votar"]. $A S$. Retrieved from https://as.com/baloncesto/2017/07/10/mas_baloncesto/1499673896_814908.html

Bairner, A. (1994). Football and the idea of Scotland. In G. Jarvie and G. Walker (Eds.) Scottish sport in the making of the nation: ninety minute patriots? (pp. 9-26). Leicester: Leicester University Press.

Bairner, A. (1996). Sportive nationalism and nationalist politics: A comparative analysis of Scotland, the Republic of Ireland, and Sweden. Journal of Sport and Social Issues, 20(3), 314-334. doi: 10.1177/019372396020003006

Bairner, A. (2000). Football. In G. Jarvie and J. Burnett (Eds.) Sport, Scotland and the Scots (pp. 87-104). East Linton: Tuckwell.

Bairner, A. (2001). Sport, nationalism and globalization: European and North American perspectives. Albany, NY: State University of New York Press. 
Bairner. A. (2015). Assessing the sociology of sport: on national identity and nationalism. International Review for the Sociology of Sport, 50(4-5), 375-379. doi: $10.1177 / 1012690214538863$

Barcelo, J., Clinton, P., \& Samper Sero, C. (2015). National identity, social institutions and political values. The case of FC Barcelona and Catalonia from an intergenerational comparison. Soccer \& Society, 16(4), 469-481. doi: 10.1080/14660970.2014.882826

BBC (2006, 29 June). Murray receives weblog hate mail. BBC News. Retrieved from http://news.bbc.co.uk/1/hi/5128028.stm

BBC (2013, 28 May). Sir Chris Hoy voices Olympic concerns for independent Scotland. BBC Sport. Retrieved from http://www.bbc.co.uk/sport/0/cycling/22693588

BBC (2014, 9 September). Referendum Live - 9 September 2014. BBC News. Retrieved from http://www.bbc.co.uk/news/live/uk-scotland-29122590

Billig, M. (1995). Banal nationalism. London: Sage.

Blain, N., Boyle, R., \& O’Donnell, H. (1993). Sport and national identity in the European media. Leicester: Leicester University Press.

Blundy, R. (2014, 18 September). Andy Murray hounded as a 'hypocrite' after coming out in support of Scottish independence. Evening Standard. Retrieved from http://www.standard.co.uk/news/uk/andy-murray-trolled-on-twitter-after-coming-outin-support-of-scottish-independence-9739840.html

Boyle, R. (2000). What football means to Scotland (or what 'fitba' tells us about Scotland!). Critical Quarterly, 42(4), 21-29. doi: 10.1111/1467-8705.00316

Boyle, R., \& Haynes, R. (1996). 'The grand old game': football, media and identity in Scotland. Media, Culture, Society, 18(4), 549-564. doi: 10.1177/016344396018004003 Brand, J. (1978). The national movement in Scotland. London: Routledge \& Kegan Paul. 
Brentin, D. (2016). 'Ready for the homeland? Ritual, remembrance and political extremism in Croatian football'. Nationalities Papers, 44(6), 860-876. doi: $10.1080 / 00905992.2015 .1136996$

Carbonell, J.-M. (2018). The two main challenges to Catalan identity. American Behavioral Scientist. Advance online publication. doi: 10.1177/0002764218763479

Castello, E., Leon-Solis, F., \& O’Donnell, H. (2016). Spain, Catalonia and the Scottish referendum: a study in multiple realities. In N. Blain, D. Hutchison, and G. Hassan (Eds.), Scotland's referendum and the media: national and international perspectives (pp. 159-172). Edinburgh: Edinburgh University Press.

Chaytor, H. J. (1933). A history of Aragon and Catalonia. London: Methuen.

Clarke, J., \& Newman, J. (2017). 'People in this country have had enough of experts': Brexit and the paradoxes of populism. Critical Policy Studies, 11(1), 101-116. doi: $10.1080 / 19460171.2017 .1282376$

Crameri, K. (2000). Banal Catalanism? National Identities, 12(2), 145-157. doi: $10.1080 / 713687691$

Crexell, J. (1994). Nacionalisme i Jocs Olímpics del 1992. Barcelona: Columna.

Crichton, T. (2014, 6 September). Independence referendum: Football legends unite to back Better Together campaign. The Daily Record. Retrieved from http://www.dailyrecord.co.uk/news/scottish-news/independence-referendum-footballlegends-unite-4173636

Cronin, M. (1999). Sport and nationalism in Ireland: Gaelic Games, soccer and Irish identity since 1884. Dublin: Four Courts Press.

Cuadras-Morato, X. (2016). Introduction: Catalonia, a new state in Europe?. In X. CuadrasMorato (Ed.), Catalonia: a new state in Europe? A debate on secession within the European Union (pp. 1-19). London: Routledge. 
de Grado, A. (2017, 5 November). Guardiola wears yellow ribbon in support of imprisoned Catalan politicians. Marca [English]. Retrieved from http://www.marca.com/en/football/internationalfootball/2017/11/05/59ff31d7e5fdea6e458b45c7.html

Dekavalla, M. (2016). Framing referendum campaigns: the 2014 Scottish independence referendum in the press. Media, Culture and Society, 38(6), 793-810. doi: $10.1177 / 0163443715620929$

Delaney, M. (2017, 2 October). Catalan referendum: Pep Guardiola reveals he voted by post in independence poll. The Independent. Retrieved from https://www.independent.co.uk/sport/football/premier-league/catalan-referendum-pepguardiola-voted-post-independence-poll-backs-region-a7976826.html

Devine, T.M. (1999) The Scottish Nation: 1700-2000. London: Penguin.

Duerr, G. (2015). Secessionism and the European Union: the future of Flanders, Scotland and Catalonia, London: Lexington.

Duke, V., \& Crolley, L. (1996). Football, nationality, and the state. Harlow: Longman.

Eiermann, M. (2016). How Donald Trump fits into the history of American populism. New Perspectives Quarterly, 33(2), 29-34. doi: 10.1111/npqu.12033

El Periodico (2017, 1 October). Piqué: "I have already voted, together we are unstoppable defending democracy" [Piqué: "Ja he votat, junts som imparables defensant la democràcia"], El Periodico. Retrieved from https://www.elperiodico.cat/ca/barca/20171001/pique-referendum-xavi-catalunyapuyol-6323663

Freeden, M. (2017). After the Brexit referendum: revisiting populism as an ideology. Journal of Political Ideologies, 22(1), 1-11. doi: 10.1080/13569317.2016.1260813 
García, C. (2012). Nationalism, identity, and fan relationship building in Barcelona Football Club. International Journal of Sport Communication, 5(1), 1-15. doi:

10.1123/ijsc.5.1.1

Greer, S. (2007). Nationalism and self-government: the politics of autonomy in Scotland and Catalonia. Albany, NY: State University of New York Press.

Guibernau, M. (1995). Nationalisms: the nation-state and nationalism in the twentieth century. Cambridge: Polity Press.

Guibernau, M. (2000). Nationalism and intellectuals in nations without states: The Catalan case. Political Studies, 48(5), 989-1005. doi: 10.1111/1467-9248.00291

Guibernau, M. (2002). Catalan nationalism: Francoism, tradition and democracy, London: Routledge.

Guibernau, M. (2014). Prospects for an independent Catalonia. International Journal of Politics, Culture, and Society, 27(1), 5-23. doi: 10.1007/s10767-013-9165-4

Gusterson, H. (2017). From Brexit to Trump: Anthropology and the rise of nationalist populism. American Ethnologist, 44(2), 209-214. doi: 10.1111/amet.12469

Hanham, H.J. (1969). Scottish nationalism. London: Faber and Faber.

Hargreaves, J. (2000). Freedom for Catalonia? Catalan nationalism, Spanish identity and the Barcelona Olympic Games. Cambridge: Cambridge University Press.

Harris, J. \& Skillen, F. (2016). Sport, gender and national identities. In N. Blain, D. Hutchison, \& G. Hassan (Eds.), Scotland's referendum and the media: national and international perspectives (pp. 83-96). Edinburgh: Edinburgh University Press.

Harvie, C. (1998). Scotland and nationalism: Scottish society and politics 1707 to the present. London: Routledge. 
Hearn, J. (2002). Narrative, agency, and mood: on the social construction of national history in Scotland. Comparative Studies in Society and History, 44(4), 745-769. doi: $10.1017 / \mathrm{S} 0010417502000348$

Hobsbawm, E. (1990). Nations and nationalism since 1780: programme, myth, reality, Cambridge: Cambridge University Press.

Inglehart, R., \& Norris, P. (2016). Trump, Brexit, and the rise of populism: Economic havenots and cultural backlash. HKS Working Paper No. RWP16-026. Available at http://dx.doi.org/10.2139/ssrn.2818659.

Iorwerth, H., Hardman, A., \& Rhys Jones, C. (2014). Nation, state and identity in international sport. National Identities, 16(4), 327-347. doi:

$10.1080 / 14608944.2014 .897316$

Jarvie, G. (1993). Sport, nationalism and cultural identity. In L. Allison (Ed.), The changing politics of sport (pp. 58-83). Manchester: Manchester University Press.

Jarvie, G. (2017). Sport, the 2014 Commonwealth Games and the Scottish referendum. In A. Bairner, J. Kelly, \& J.W. Lee (Eds.), The Routledge handbook of sport and politics (pp. 209-221). London: Routledge.

Jarvie, G., \& Reid, I. (1999). Scottish sport, nationalist politics and culture. Culture, Sport, Society, 2(2), 22-43. doi: 10.1080/14610989908721837

Jarvie, G., \& Walker, G. (1994). Ninety minute patriots? Scottish sport in the making of the nation. In G. Jarvie \& G. Walker (Eds.), Scottish sport in the making of the nation: Ninety minute patriots? (pp. 9-26). Leicester: Leicester University Press.

Johnson, S. (2013, 30 May). Chris Hoy called a traitor to Scotland by nationalists. The Telegraph. Retrieved from http://www.telegraph.co.uk/news/uknews/scotland/10087642/Nationalists-call-SirChris-Hoy-a-traitor-to-Scotland.html 
Judis, J. B. (2016). The populist explosion: How the great recession transformed American and European politics. New York, NY; Columbia Global Reports.

Kassimeris, C. (2012). Franco, the popular game and ethnocentric conduct in modern Spanish football. Soccer \& Society, 13(4), 555-569. doi: 10.1080/14660970.2012.677228

Kazin, M. (2016). Trump and American populism: Old whine, new bottles. Foreign Affairs, 95, 17. Retrieved from https://www.foreignaffairs.com/articles/united-states/2016-1006/trump-and-american-populism

Keating, M. (1996). Nations against the state: the new politics of nationalism in Quebec, Catalonia and Scotland. New York, NY: St Martin's Press.

Kellner, D. (2016). American nightmare: Donald Trump, media spectacle, and authoritarian populism. Boston, MA: Sense Publishers.

Kowalski, R. (2004). 'Cry for us, Argentina': sport and national identity in late twentiethcentury Scotland. In A. Smith \& D. Porter (Eds.), Sport and national identity in the post-war world (pp. 69-87). London: Routledge.

Lafferty, S. (2014). 'Stars of sport say Yes to an independent Scotland'. Yes Scotland. Retrieved from http://www.yesscotland.net/news/stars-sport-say-yes-independentscotland

Landaluce, E. (2017, 13 November). Marc Márquez's dice trick [Los dados trucados de Marc Márquez]. El Mundo. Retrieved from http://www.elmundo.es/deportes/motociclismo/2017/11/13/5a08982546163f6f168b45e b.html

Larkin, P. (2011). The politics of coalition in Scotland. Political Science, 63(1), 61-78. doi: $10.1177 / 0032318711404023$

Leith, M.S., and Soule, D.P.J. (2011) Political discourse and national identity in Scotland. Edinburgh: Edinburgh University Press. 
Llopis-Goig, R. (2014). The predominance of soccer in the sport and leisure habits of Spanish society. Sport in Society, 17(6), 824-841. doi: 10.1080/17430437.2014.882909

Llorens, M. (2018, 23 February). Police search Pep Guardiola's plane looking for Puigdemont. $A S$. Retrieved from https://en.as.com/en/2018/02/23/football/1519394172_535851.html

Lopez-Gonzalez, H., Guerrero-Sole, F., \& Haynes, R. (2014). Manufacturing conflict narratives in Real Madrid versus Barcelona football matches. International Review for the Sociology of Sport, 49(6), 688-706. doi: 10.1177/1012690212464965

Lowe, S. (2017, 4 October). Gerard Piqué: 'Why can a journalist or a mechanic express themselves but not a footballer?'. The Guardian. Retrieved from https://www.theguardian.com/football/2017/oct/04/gerard-pique-catalan-referendumfootballer-express-himself

Lynch, P. (2009) From social democracy back to no ideology? The Scottish National Party and ideological change in a multi-level electoral setting, Regional \& Federal Studies, 19(4-5), 619-637.

Maclean, F. (2000). Scotland: a concise history. London: Thames and Hudson.

Maguire, J. (1999). Global sport. Cambridge: Polity Press.

Marca (2012, 19 November). Oleguer: "I know there were other cases like mine for Spain". Marca [English]. Retrieved from http://www.marca.com/2012/11/19/en/football/national_teams/1353353466.html Marca (2015, 22 September). Pau Gasol: "I don't like my words being twisted". Marca [English]. Retrieved from http://www.marca.com/en/2015/09/22/en/more_sports/1442953297.html Marca (2017a, 11 June). Guardiola: Catalans will vote on independence even though Spain doesn't want us t., Marca [English]. Retrieved from 
http://www.marca.com/en/football/spanishfootball/2017/06/11/593d35bb22601df1108b45e6.html

Marca (2017b, 1 October). Guardiola: They say it was the police officers who were injured. Injured by what? By votes? Marca [English]. Retrieved from http://www.marca.com/en/football/barcelona/2017/10/01/59d14f5a22601d11718b457e. html

Martinez, J. (2017, 11 September). Rafa Nadal: "The Referendum in Catalonia should not happen, it's like skipping a red light" [Rafa Nadal: "El Referéndum de Cataluña no debe producirse. Es como saltarse un semáforo en rojo"]. El Mundo. Retrieved from http:/www.elmundo.es/deportes/tenis/2017/09/11/59b6f82122601db8068b45e0.html

McCrone, D. (1992). Understanding Scotland: the sociology of a stateless nation: London: Routledge.

McCrone, D. (2005). Cultural capital in an understated nation: the case of Scotland. The British Journal of Sociology, 56(1), 65-82. doi: 10.1111/j.1468-4446.2005.00047.x

McCrone, D. (2017). The new sociology of Scotland. London: Sage.

McDowell, M. \& Skillen, F. (2015). The 1986 Commonwealth Games: Scotland, South Africa, sporting boycotts, and the former British Empire. Sport in Society, 20(3), 384397. doi: $10.1080 / 17430437.2015 .1088725$

McFarland, A. (2013). Founders, foundations and early identities: football's early growth in Barcelona. Soccer \& Society, 14(1), 93-107. doi: 10.1080/14660970.2013.767723

McLeman, N. (2016, 22 April). Andy Murray admits he's keeping quiet on the Brexit debate after Scottish independence controversy. Daily Mirror. Retrieved from http://www.mirror.co.uk/sport/football/news/andy-murray-admits-hes-keeping-7812620 
Micó, J. L., \& Carbonell, J. M. (2017). The Catalan political process for independence: an example of the partisan media system. American Behavioral Scientist, 61(4), 428-440. doi: $10.1177 / 0002764217693277$

Miller, T., Lawrence, G., McKay, J., \& Rowe, D. (2001). Globalization and sport. London: Sage.

Mols, F., \& Jetten, J. (2016). Explaining the appeal of populist right-wing parties in times of economic prosperity. Political Psychology, 37(2), 275-292. doi: 10.1111/pops.12258

Moffitt, B., \& Tormey, S. (2014). Rethinking populism: Politics, mediatisation and political style. Political Studies, 62(2), 381-397. doi: 10.1111/1467-9248.12032

Mudde, C., \& Kaltwasser, C. R. (Eds.). (2012). Populism in Europe and the Americas: Threat or corrective for democracy? Cambridge: Cambridge University Press.

Mullen, T. (2014). The Scottish independence referendum 2014. Journal of Law and Society, 41(4), 627-640. doi: 10.1111/j.1467-6478.2014.00688.x

Mycock, A. (2012) SNP, identity and citizenship: re-imagining state and nation, National Identities, 14(1), 53-69.

Nili, S. (2009). The rules of the game - nationalism, globalisation and football in Spain: Barça and Bilbao in a comparative perspective. Global Society, 23(3), 245-268. doi: $10.1080 / 13600820902958014$

O’Brien, J. (2013). 'El Clasico' and the demise of tradition in Spanish club football: perspectives on shifting patterns of cultural identity. Soccer \& Society, 14(3), 315-330. doi: $10.1080 / 14660970.2013 .801263$

Olivieri, V. M. (2015). Sub-state nationalism in Spain: primers and triggers of identity politics in Catalonia and the Basque Country. Ethnic and Racial Studies, 38(9), 16101626. doi: 10.1080/01419870.2015.1009480 
Ordeix, E. \& Ginesta, X. (2014). Political engagement principles as the basis for new regional self-determination processes in Europe: the case of Catalonia. American Behavioral Scientist, 58(7), 928-940. doi: 10.1177/0002764213506214

Pittock, M. (2008) The road to independence? Scotland since the sixties. London: Reaktion.

Pittock, M. (2012). Scottish sovereignty and the union of 1707: then and now. National Identities, 14(1), 11-21. doi: 10.1080/14608944.2012.657082

Polley, M. (2004). Sport and national identity in contemporary England. In A. Smith \& D. Porter (Eds.), Sport and national identity in the post-war world (pp. 10-30). London: Routledge.

Prado, E. (2015). The press in Catalonia: between the digital challenge and nation building. Media, Culture \& Society, 37(1), 134-143. doi: 10.1177/0163443714553563

Prynne, M. (2014, 23 September). Andy Murray: I regret my 'let's do this!' tweet but back Scottish independence. The Telegraph. Retrieved from http://www.telegraph.co.uk/news/uknews/scottish-independence/11115050/AndyMurray-I-regret-my-lets-do-this-tweet-but-back-Scottish-independence.html

Pujol, A. \& Yuba, E. (2014). Constructing the national through sports news in Catalonia (2007-2009). Catalan Journal of Communication and Cultural Studies, 6(2), 239-256. doi: $10.1386 /$ cjes.6.2.239_1

Roden, A. (2013, 29 May). Cycling hero Sir Chris Hoy branded a 'bigot' by Scottish nationalists in online campaign of abuse after raising concerns about independence. Daily Mail Online. Retrieved from http://www.dailymail.co.uk/news/article2332868/Cycling-hero-Sir-Chris-Hoy-branded-bigot-Scottish-nationalists-onlinecampaign-abuse-raising-concerns-independence.html.

Ruiz, C. (2017, 1 October). Piqué gets excited, defends Catalunya and charges hard against Rajoy [Piqué se emociona, defiende a Catalunya y carga duro contra Rajoy], $L a$ 
Vanguardia. Retrieved from

http://www.lavanguardia.com/deportes/futbol/20171001/431712404175/piquebarcelona-las-palmas-rajoy.html

Ruiz, M. (2017, 28 September) Oleguer, the referendum ... and Piqué: "The serious thing is not being able to make a tweet to ask for the right to self-determination" [Oleguer, el referéndum... y Piqué: "Lo grave es no poder hacer un tuit para pedir el derecho a la autodeterminación"]. Marca. Retrieved from http://www.marca.com/futbol/barcelona/2017/09/28/59cd4cb1468aebe84e8b45aa.html Scottish Government (2013a). Working Group on Scottish Sport interim statement. Edinburgh: Scottish Government. Retrieved from http://www.gov.scot/Resource/0043/00437896.pdf

Scottish Government (2013b). Scotland's future: your guide to an independent Scotland. Edinburgh: Scottish Government. Retrieved from http://www.gov.scot/Publications/2013/11/9348/downloads

Scottish Government (2014). Working Group on Scottish Sport: the continuing development of Scottish sport - including the impact of independence. Edinburgh: Scottish Government. Retrieved from: http://www.gov.scot/Resource/0044/00449792.pdf

Schlesinger, P., \& Benchimol, A. (2014). Small nations, the press and the digital challenge. Media, Culture \& Society, 37(1), 101-106. doi: 10.1177/0163443714553561

Sharp, J., Cumbers, A., Painter, J. \& Wood, N. (2014). Deciding whose future? Challenges and opportunities of the Scottish independence referendum 2014 for Scotland and beyond. Political Geography, 41, 32-42. doi: 10.1016/j.polgeo.2014.04.002

Shipman, T. (2014, 8 June). Murray tells Salmond to put his saltire away. The Sunday Times. Retrieved from http://www.thesundaytimes.co.uk/sto/news/uk_news/scotland/article1420257.ece 
Shobe, H. (2006). Place, sport and globalization: Making sense of la marca Barça. Treballs de la Societat Catalana de Geografia, 61-62, 259-276. Retrieved from https://www.raco.cat/index.php/TreballsSCGeografia/article/view/256647

Shobe, H. (2008). Place, identity and football: Catalonia, Catalanisme and Football Club Barcelona, 1899-1975. National Identities, 10(3), 329-343. doi: $10.1080 / 14608940802249965$

Silk, M., Andrews, D., \& Cole, C. (Eds.) (2005). Sport and corporate nationalisms. Oxford: Berg.

Smith, A.D. (1999). Myths and memories of the nation. Oxford: Oxford University Press. Sport (2015, 18 September). Oleguer Presas: "What the Spanish national team represents repelled me" [Oleguer Presas: "Lo que representa la selección española me generaba rechazo"], Sport. Retrieved from https:/www.sport.es/es/noticias/barca/oleguer-presasque-representa-seleccion-espanola-generaba-rechazo-4518188

Sport (2017a, 29 September). Oleguer: Pique's tweet was brave because we all know it brings consequences. Sport [English]. Retrieved from https://www.sportenglish.com/en/news/barca/oleguer-piques-tweet-was-brave-because-we-all-know-itbrings-consequences- 6319498

Sport (2017b, 22 December). Guardiola: "Yesterday it was clear what Catalonia wants" [Guardiola: "Yesterday it was clear what Catalonia wants]. Sport. Retrieved from https://www.sport.es/es/noticias/premier-league/guardiola-ayer-quedo-claro-quequiere-cataluna-6513799

Sport (2017, 4 October). Pique's response when asked if he's in favour of Catalan independence. Sport [English]. Retrieved from https://www.sportenglish.com/en/news/piques-response-when-asked-if-hes-in-favour-of-catalanindependence-6331113 
Stout, J. (2016). Breakaway nations: the use of sport and physical culture to create a cross class Catalan identity during the Second Republic (Unpublished doctoral thesis). University of California, San Diego.

Swanson, I. (2013, 30 May). Scottish independence: Chris Hoy 'abused' online. The Scotsman. Retrieved from http://www.scotsman.com/news/scottish-independencechris-hoy-abused-online-1-2948290

The Guardian (2018, 23 February). FA charges Pep Guardiola over Catalonia yellow ribbon, The Guardian. Retrieved from https://www.theguardian.com/football/2018/feb/23/manchester-city-pep-guardiolayellow-ribbon-charge-fa-catalonia

The Herald (2014, 10 September). Silver medallist Lynsey Sharp: FM's being unfair to Novoting Scots with his Team Scotland label. The Herald. Retrieved from http://www.heraldscotland.com/news/13179296.Silver_medallist_Lynsey_Sharp_FM _s_being_unfair_to_No_voting_Scots_with_his_Team_Scotland_label

The Telegraph (2017, 2 October). Pep Guardiola condemns decision to play Barcelona vs Las Palmas behind closed doors, The Telegraph. Retrieved from https://www.telegraph.co.uk/football/2017/10/02/pep-guardiola-condemns-decisionplay-barcelona-vs-las-palmas/

Torres, D. (2017a, 30 September). The statements of Piqué bring the Catalan crisis to the Spanish team [Les declaracions de Piqué porten la crisi catalana a la selecció espanyola]. El Pais. Retrieved from https://cat.elpais.com/cat/2017/09/29/catalunya/1506712390_279626.html

Torres, D. (2017b, 3 October). "Piqué gets wet for something that affects us all" ["Piqué se moja por algo que nos afecta a todos"], El Pais. Retrieved from https://elpais.com/deportes/2017/10/02/actualidad/1506974819_745273.html 
Tronchoni, N. (2017, 13 November). Why doesn’t MotoGP champion Marc Márquez celebrate with the Spanish flag? El Pais [English]. Retrieved from https://elpais.com/elpais/2017/11/13/inenglish/1510572136_508939.html

Tunon, J., \& Brey, E. (2012). Sport and politics in Spain - football and nationalist attitudes within the Basque Country and Catalonia. European Journal for Sport and Society, 9(12), 7-32. doi: 10.1080/16138171.2012.11687887

Vaczi, M. (2015). "The Spanish Fury": A political geography of soccer in Spain. International Review for the Sociology of Sport, 50(2), 196-210. doi: $10.1177 / 1012690213478940$

Vaczi, M. (2017a). Sport, identity and nationalism in the Hispanic world. Studia Iberica et Americana, 4(4), 17-34. Retrieved from http://www.studia-ibericaamericana.com/data/100172/assets/Issues/Siba2017@1518966639283.pdf\#page=17

Vaczi, M. (2017b). Pulling up stakes? Sport and sub-national solidarity for Catalonia's independence. Studia Iberica et Americana, 4(4), 155-178. Retrieved from http://www.studia-ibericaamericana.com/data/100172/assets/Issues/Siba2017@1518966639283.pdf\#page=17

Weisbloom, D. (2012, 11 September). Andy Murray: do sport and politics mix? Channel 4 News. Retrieved from http://www.channel4.com/news/andy-murray-sport-and-politicscollide

West, A. (2017, 1 October). Catalan referendum: How FC Barcelona found themselves at centre of issue. BBC Sport. Retrieved from https://www.bbc.co.uk/sport/football/41461197

Whaling, J. (2017, 21 December). Pep Guardiola 'under investigation by Spanish police for 'rebelling' during Catalan referendum process, The Daily Mirror. Retrieved from 
https://www.mirror.co.uk/sport/football/news/pep-guardiola-under-investigationspanish-11735399

Whigham, S. (2014). 'Anyone but England'? Exploring anti-English sentiment as part of Scottish national identity in sport. International Review for the Sociology of Sport, 49(2), 152-174. doi: 10.1177/1012690212454359

Whigham, S. \& May, A. (2017). 'Sport for Yes'? The role of sporting issues in proindependence political discourse during the Scottish independence referendum campaign. International Journal of Sport Policy and Politics, 9(3), 557-572. doi: $10.1080 / 19406940.2017 .1313299$

Whitaker, A. (2014, 12 September). Scottish independence: Rugby legends backing 'No'. The Scotsman. Retrieved from http://www.scotsman.com/news/politics/scottishindependence-rugby-legends-backing-no-1-3539854

Whittell, I. (2018, 28 February). Pep Guardiola ready to give up 'yellow ribbon' Catalonia protest at City's request, AFP News / Yahoo. Retrieved from https://sg.news.yahoo.com/guardiola-ready-yellow-ribbon-catalonia-protest-citysrequest-224112367--sow.html?guccounter=1

Wodak, R. (2015). The politics of fear: What right-wing populist discourses mean. London: Sage.

Wodak, R., KhosraviNik, M., and Mral, B. (Eds.). (2013). Right-wing populism in Europe: Politics and discourse. London: Bloomsbury.

Xifra, J. (2009). Building sport countries' overseas identity and reputation: A case study of public paradiplomacy. American Behavioral Scientist, 53(4), 504-515. doi: $10.1177 / 0002764209347627$ 
Y1lmaz, F. (2012). Right-wing hegemony and immigration: How the populist far-right achieved hegemony through the immigration debate in Europe. Current Sociology, 60(3), 368-381. doi: 10.1177/0011392111426192 